\title{
BARRIERS TO START AND DEVELOP TRANSFORMATIVE ECOTOURISM BUSINESS
}

\section{Dalia Vidickiené ${ }^{1}$, Zivile Gedminaite-Raudone ${ }^{2}$, Rita Vilke ${ }^{3}$, Pawel Chmielinski ${ }^{4}$, Aija Zobena ${ }^{5}$}

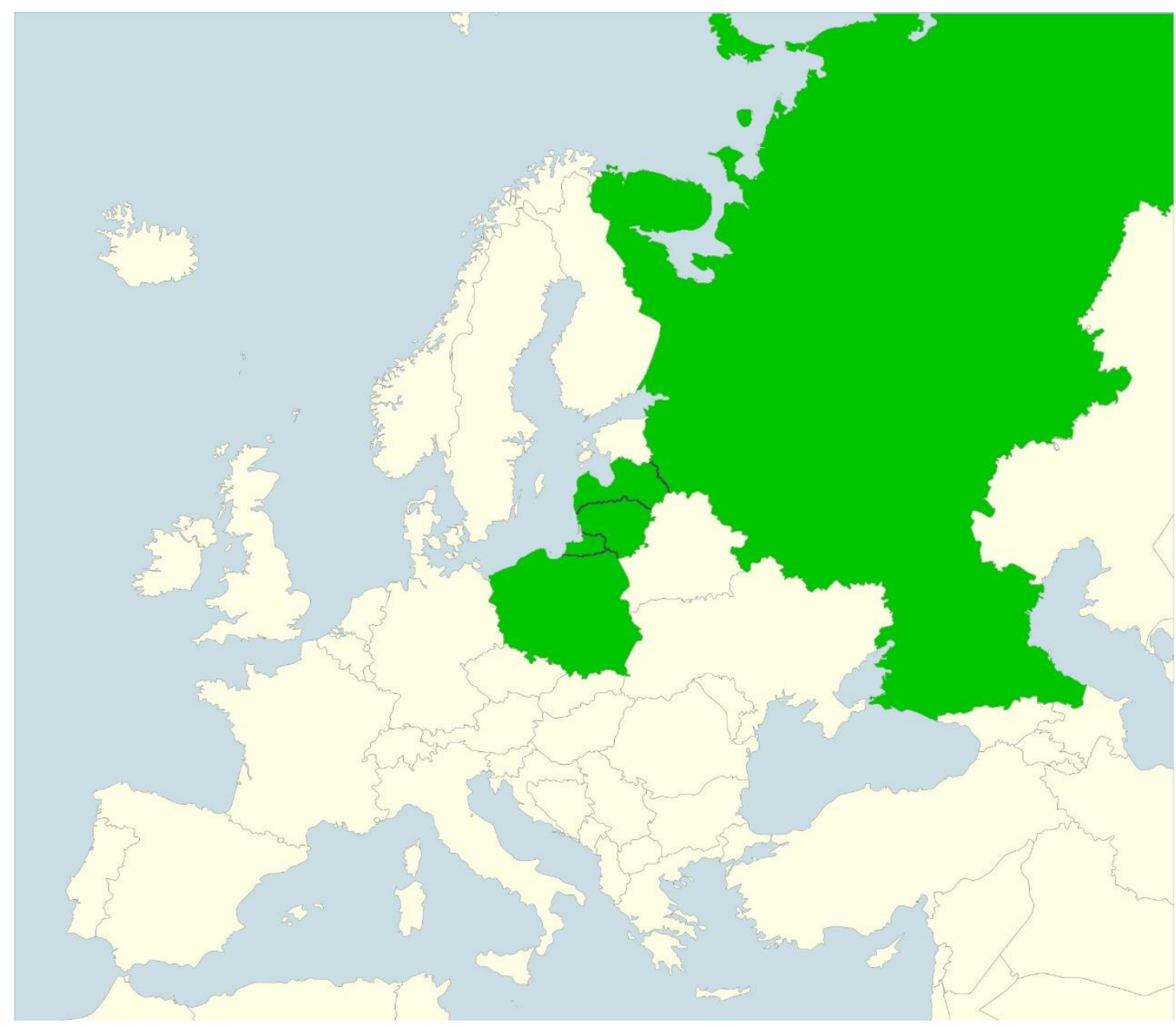

\footnotetext{
${ }^{1}$ Dr. Dalia Vidickienè, Lithuanian Centre for Social Sciences, Institute of Economics and Rural Development, Vilnius, Lithuania; ORCID: 0000-0002-0892-5601, e-mail: dalia@laei.It

2 Dr. Živilè Gedminaitè-Raudonè, Lithuanian Centre for Social Sciences, Institute of Economics and Rural Development, Vilnius, Lithuania; ORCID:0000-0001-8437-5368, e-mail: zivile@laei.It

3 Dr. Rita Vilke, Lithuanian Centre for Social Sciences, Institute of Economics and Rural Development, Vilnius, Lithuania; ORCID: 0000-0003-3112-5415, e-mail: rita.vilke@laei.It

${ }^{4}$ Dr. Paweł Chmieliński, President of the European Rural Development Network and Professor at the Institute of Rural and Agricultural Development, Polish Academy of Sciences; Warszawa, Poland; ORCID: 0000-0001-8377-0702; email: pawel.chmielinski@gmail.com

${ }^{5}$ Prof. Aija Zobena, director of the Advanced Social and Political Research Institute, Faculty of Social Sciences, University of Latvia; Riga, Latvija; ORCID: 0000-0003-4660-2886; e-mail: aija.zobena@lu.Iv
} 
Abstract: This article aims to fill the cognitive gap by providing evidence for different barriers hampering the innovative activity in ecotourism which concerns the promotion of the so-called transformative tourism concept. The research is devoted to identifying what are the most important barriers in the two areas: i) policy and regulation; ii) regional economic development. The observed absence of appropriate representative data for defining the state of the art in the field of transformative ecotourism as a new phenomenon is evident; therefore, it is suggested to use an expert survey for barriers identification in the field. The expert survey was done in the four post-socialist Baltic Sea countries/regions: Latvia, Lithuania, Poland, and the St. Petersburg region (Russia) in autumn 2020. Research results disclose the existing similarities among barriers in researched regions and highlight the key areas for improvement in policy and regulation and economy-related fields, aiming to create a more favorable environment for promoting transformative ecotourism as prosperous innovation of future tourism.

Key words: eco-innovation, ecotourism, policy, regional economic development, servitization, transformative tourism

Santrauka: Šiuo straipsniu siekiama užpildyti žinių, susijusių su transformatyvaus turizmo plètra, spragą, analizuojant kliūtis šios inovatyvios koncepcijos plètotei ekologiniame turizme. Tyrimas skirtas nustatyti, kokios yra svarbiausios transformatyvaus ekoturizmo plètotès kliūtys dviejose srityse: i) politika ir reguliavimas; ir ii) regiono ekonomika. Kadangi nèra tinkamų reprezentatyvių duomenų, kuriais remiantis būtų galima apibūdinti, kiek ši inovacija diegiama ekoturizmo sektoriuje bei nustatyti kliūtis jos plètotei, tyrime naudojamas ekspertu apklausos metodas. Ekspertu apklausa buvo atlikta $2020 \mathrm{~m}$. rudeni keturiose postsocialistinèse Baltijos jūros regiono šalyse: Latvijoje, Lietuvoje, Lenkijoje ir Sankt Peterburgo regione (Rusija). Tyrimo rezultatai atskleidžia tirtụ regionų panašumus tranformatyvaus ekoturizmo vystymo kliūčių požiūriu ir išryškina pagrindines tobulintinas politikos, reguliavimo bei ekonomikos sritis, siekiant sukurti palankesnę aplinką transformatyvaus ekoturizmo kaip perspektyvios inovacijos turizmo versle skatinimui.

Raktiniai žodžiai: eko-inovacija, ekoturizmas, politika, regiono ekonomika, servitizacija, transformatyvus turizmas

\section{Highlights:}

- A new generation of ecotourism services based on the concept of transformative tourism is introduced

- The transformative ecotourism business in four Baltic Sea region countries from an organizational perspective is described

- The evidence for different barriers hampering the innovative activity in ecotourism is highlighted

- The most important barriers of the transformative ecotourism business development in policy and regulation and regional economic development areas are identified

\section{Introduction}

Ecotourism as a tourism sub-industry emerged in the 1980s as a direct result of the world's acknowledgment and reaction to global ecological practices (Diamantis, 1999). It has been promoted by governments as an innovation capable of protecting the ecosystems and foster environmentally responsible behaviour, and at the same time creating jobs and generating 
income for local communities. The popularity of this form of tourism was high; it was estimated that tourism in the natural and wildlife settings accounted for a total $20-40 \%$ of international tourism receipts (Filion et al., 1994). Ecotourism was claimed to be the fastest-growing tourism segment around the world. According to a study of Starmer-Smith (2004), the number of ecotourists was growing three times faster than the conventional tourists.

Many ecotourism proponents argue that ecotourism still is a fast-growing industry (e.g., Das, 2011; Fennel, 2020). However, part of scholars and travelers have become more critical about the idea to blindly accept the claims that mass tourism destinations are ecotourism destinations. First of all, they are challenging the legitimacy of many players to call themselves ecotourism destinations. As pointed out in several studies, there are many cases of tourist projects being labeled as ecotourism either by companies to attract tourists or indeed by governments to attract funding and legitimize tourist development policies (Carrier \& Macleod 2005; Gray \& Campbell 2007; Das \& Chatterjee, 2015; Wondirad, 2019). The result is a proliferation of projects which adopt the ecotourism name without espousing sustainability goals, with all the accompanying negative environmental and social effects associated with mass tourism.

Secondly, the special benefits of ecotourism also have been challenged through empirical research. Ecotourism has been accused as a source of a wide range of negative impacts both to the nature of the destination and to indigenous communities. Scholars criticize ecotourism as a wildlife conservation strategy for its inability to ensure the long-term protection of environmental assets as market-based conservation strategies. The rise in the number of tourists, which exceeds the carrying capacity of the place, leads to natural resource depletion, pollution (i.e., air, water, sound, and waste), soil erosion, and loss of wildlife habitat in conjunction with the risk of forest fires for which tourists come (McCauley, 2006; Drumm, 2008; Monti et al, 2018). A metaanalysis by Wardle et al. (2018), which examines ecotourism's contribution to conservation uncovered that even though there are successful cases in different parts of the world, on the larger scale, however, the conservational impact of ecotourism remains elusive. The worry about ecotourism growth management also emerged concerning effects of ecotourism to local communities because of lack of collaborative approach and incompetence to create a "win-win" situation for both the host community and the travelers (Peake et al, 2006; Mitchell \& Ashley, 2010; Butcher, 2011; Kim et al., 2019; Lee, 2019). Such situation encourages scholars to ask the question: "Does ecotourism contribute to sustainable destination development, or is it just a marketing hoax?" (McShane et al., 2011; Coria \& Calfucura, 2012; Erdoğan, 2017; Ruhanen, 2019; Wondirad, 2019). As pointed out by Wondirad (2019), which analyzed twenty-five years tourism journals publications on ecotourism, the overall contribution of ecotourism towards ensuring a sustainable destination development remains elusive implying that, thus far, ecotourism has been used mainly as a marketing tactic.

The particular attention regarding the growing importance of the issue had been lately expressed by the European Union by accelerating new scientific and research activities in the field of new prospective forms of tourism, including transformative ecotourism, which, at the same time, would enable to solve socio-economic issues of rural areas. For instance, the Horizon2020 call had lately addressed cultural tourism through the activity "TRANSFORMATIONS-04-2019-2020: Innovative approaches to urban and regional development through cultural tourism" (Call for Proposals..., 2020). Furthermore, the "Report on Sustainable Tourism in the Baltic Sea Region" (2020) considers, that "in 2020, Policy Area Tourism supported four seed money projects from different thematic fields of tourism", among these - the project „RESTinBSR“ (p.17), which aims at unlocking transformative ecotourism potential for sustainable regional development. All these newly proposed funding opportunities demonstrate the call for ideas in innovations in tourism, at the same time issuing, that the current state of the tourism situation should be necessarily changed, and new forms should be elaborated for further developments in the field. Thus, the transformative ecotourism, as innovation in tourism, had been awarded for further elaboration in the field (Report on Sustainable Tourism in the Baltic Sea Region, 2020), as an emerging issue in tourism, thus starting its pathway among the "Main Developments in the Field of Sustainable Tourism" in the EU and non-EU countries around the Baltic Sea, folowing the European Union Strategy for the Baltic Sea Region. 
Despite clear signs of crisis in the realization of ecotourism vision defined by the International Ecotourism Society as "responsible travel to natural areas that conserves the environment, sustains the well-being of the local people, and involves interpretation and education" (TIES, 2015), the discussions on the evolution of ecotourism vision are very rare. According to the study by Wondirad (2019), which analyzed 470 articles published in nine top-tier tourism journals between 1993 and 2018, ecotourism development challenges as the leading ecotourism research theme appeared in only 10 articles comprising $2.1 \%$ of the entire publication. A comprehensive bibliometric analysis of 878 articles on ecotourism also shows that no new directions in ecotourism research arose from 2012 till 2019 (Khanra et al., 2021). To fill this literature gap, this paper discusses the barriers to the new evolutionary path in ecotourism development - transformative ecotourism. This currently emerging innovative form of ecotourism occurs as a part of the sociocultural evolution of the society from the industrial to the post-industrial stage and suggests essential qualitative reorganization of ecotourism vision according to shift from ecocentric to post-anthropocentric ecological thinking. Social media and academic research show that several projects of transformative ecotourism have been launched in each developed country. However, any effort to research the transformative ecotourism business from an organizational perspective is almost non-existent. The literature on tourism innovation management and policy is still very fragmentary, and in many cases not covered by an empirical investigation. One of those areas rarely explored empirically concerns barriers to innovation in tourism (Hjalager, 2010). The lack of a comprehensive approach to innovation governance raises important inefficiencies concerning new knowledge absorption, accumulation, transfer, and integration (Sorensen, 2011). Therefore, the aim of the article is to fill the cognitive gap by providing evidence for different barriers hampering the innovative activity in ecotourism which concerns the promotion of transformative tourism concept.

\section{Theoretical background}

The term "ecotourism" is often used as a synonym of green, sustainable, and responsible, tourism. However, all mentioned synonyms are describing the characteristic of travel and are an aspiration for the impacts of all forms of tourism. Ecotourism refers to a niche segment of tourism, which arose into a large subdivision of the tourism industry during the last decades. The vision of ecotourism as a specific type of tourism has been designed in the frame of industrial era worldview and is based on the ethical thought concerning human's relationship to nature and product-driven business model. As a new sub-industry of tourism, ecotourism was first defined as "... traveling to relatively undisturbed or uncontaminated natural areas with the specific objective of studying, admiring, and enjoying the scenery and its wild plants and animals, as well as any existing cultural manifestations (both past and present) found in these areas" (CeballosLascurain, 1987: 14). Starting from the 1970s, there was a period that saw the expansion of protected areas across the world. The ecotourism industry emerged as a key promoter of innovative products - protected natural areas. This innovation has been based on the concerns of ecological movements about the need to protect the most valuable natural environments. National parks and reserves have become innovative tourism products and a task of tourism managers was offering them to the tourist market by a push marketing strategy. The moment to start new tourism market formation was very favorable as worldwide interest in the natural environment was growing. Ecotourism product demand was based upon the desires of individuals to experience nature, in all the diversity and richness that wild nature provides. The increasing interest in biodiversity has directed ecotourists to travel into exotic and often endangered places. Traveling to various national parks and reserves also became a logical response to the evolving need of the population to have a rest in the environmentally clean areas as relaxation in a natural environment was qualified as the most important need for ecotourists (McCool \& Lime, 2001; Page \& Dowling, 2002; Panin \& Mbrica, 2014; Carvache-Franco et al., 2019).

Natural areas have been tourism destinations for centuries; however, ecotourism as a form of special interest tourism emerged as a result of the changes in Western ecological thinking. The ecotourism concept has been created on the basis of the ecocentric view (Collins, 1999, Duffy, 2002; Holden; 2003; Tully, 2001; Macbeth, 2005) and as a new sub-industry of tourism started from the main idea of ecocentrism to preserve the highly valuable worldwide primitive 
natural environment by creating various conservation areas and introducing them to the public. However, over the last decades, the ecological thinking has evolved and in parallel to nature conservation suggests many various eco-innovations. The so-called Grand Challenges of the twenty-first century, including resource scarcity, climate change, demographic aging, and global security encourages a shift from ecocentrism to a post-anthropocentric attitude based on the constant search for a most appropriate method of place-based collaboration between humans and nature, which can generate and maintain the positive synergetic effect. New eco-solutions aiming for humans and nature symbiosis building by eco-innovations are inspiring radical changes in consumption patterns, lifestyles, and values. In response, a specific innovative type of travel is emerging - transformative tourism. Till now, transformative travels were mostly oriented on spiritual cultural practices. The needs for self-transformation have been realized mainly by religious, pilgrimage, yoga forms of tourism. Growing expectations of tourists to use travel for becoming a part of post-anthropocentric ecological movements imply the need for a complete metamorphosis of ecotourism destinations. Transformative tourists have more goals than observation of the visited object. The segment of transformative tourists differs by its deliberate intention to use travel for transformation. Getting involved in transformative travels is based on the same reasons as transformative learning - frustration with the current situation and the search for something new (Vidickiene et al., 2020), and ecotourists are traveling with the hope to find for themselves the most relevant eco-innovation. Changing ecotourists' needs are fostering a rise of a new generation of ecotourism services based on the concept of transformative tourism. Case studies on transformative tourism initiatives dealing with ecological issues show that the attractions of new generation ecotourism are concentrated to the best eco-projects that demonstrate fundamentally changing eco-thinking and lifestyle and are ready to share their knowledge and experience with tourists.

The shift from nature observation to transformative learning in the ecotourism business helps realize entrepreneurs involved in eco-innovations. Currently, there is an abundance of ecoinnovations in agricultural and building technologies, eating culture, health care, and recreation by animal and plant therapy, settlement planning, etc. The creation and implementation of ecoinnovations take place in a variety of communities, enterprises, and farms. Many ecovillages, ecofarms, eco-healing centers, and other eco-projects are open to tourists. Supplementing their core business with tourism services, the eco-innovators maintain a desirable lifestyle and promote it in society.

Analysis of case studies on transformative tourism initiatives dealing with ecological issues shows that key players in the development of transformative ecotourism are not traveling agencies but entrepreneurs involved in the creation and implementation of eco-innovations. Most of them use a business model called "Product plus Service System" (Reisinger, 2015; Perdomo, 2016; Vidickiene et al., 2019; Vidickiene et al., 2020) and become a provider of the new generation of ecotourism services. The involvement of new players in the ecotourism business based on the servitization concept creates an opportunity to offer services of more high quality because transformative ecotourists hope to acquire not only formal, codified tangible knowledge. The tour guides employed by tourism agencies usually are trained on the basis of codified knowledge and are not able to convey to tourists all subtle nuances of eco-innovation. More effective learning occurs in such cases when providers of tourism services are not specialized travel agencies, but enterprises or local communities engaged in experimental practices with specific eco-innovation. Managers of such projects involve tourists in various transformative learning issues dealing with technical aspects of new eco-thinking in everyday life (eco-housing, symbiotic agriculture, responsible waste management, heating, planning of living place, etc.) or with organizational and social aspects of more collaborative solutions in communal life (e.g., Palojärvi et al., 2013; Reisinger, 2013 and 2015; Vidickiene, 2013; Perdomo, 2016). The providers of a new generation of ecotourism services are offering the best travel destinations for learning how to change itself and a society concerning currently most recent issues by the implementation of specific ecosolutions. Such eco-tourism projects become an important informal educational tool for building the eco-innovation capacity of tourists and spreading the innovative eco-thinking and acting in society. 
The creation and implementation of eco-innovations take place in a variety of enterprises and communities. Most of such projects have the potential to become new ecotourism destinations by adding to the main activities of the enterprise or community the provision of transformative teaching and hospitality services for tourists. However, the eco-innovators need promotion and support by governmental institutions in the process of their business servitization. Effective promotion of transformative ecotourism as an important part of territorial servitization by innovation policy measures is impossible without a clear understanding of what types of barriers are found by businessmen, policy-makers from government, academia representatives from universities and research institutes, civil society activists involved in activities of social-ecological movements, and other stakeholders dealing with the concept of transformative ecotourism to design regional public policies to boost these activities. All the agents involved must know the incentives for and barriers to start and develop transformative ecotourism business.

\section{Methodology}

The review of various sources of literature elucidates the nonexistence of any appropriate data specifically in the field of transformative ecotourism, despite the numerous tourism statistics in general. Most of the scientific findings concerning transformative ecotourism are linked to the particular case studies, thus indirectly referring to a huge challenge for further developments in the field. This research aims to identify the barriers of emerging transformative ecotourism phenomena as a starting basis for further empirical research in the field. The proposed methodology is devoted to identifying the key barriers for transformative ecotourism development in a particular country and/or region. In turn, this will serve in composing the set of objectives that are vital to creating starting conditions to promote further developments in the field.

Stating the fact, that the absence of appropriate representative data for defining the state of the art in the field of transformative ecotourism as new phenomena is evident, qualitative research based on expert survey method, despite its limitations (e.g., Budge, 2000; Wiesehomeier et al., 2018), is found promising in solving the issue due to particular reasons: first, compared to alternative strategies, the expert survey method helps measure new and complex concepts in diverse contextual settings (Norris \& Skaaning, 2016); and second, the expert survey is used when knowledge of particular phenomena is scarce (Schedler, 2012). The research covers four postsocialist countries, which represent the Baltic Sea Region: Latvia, Lithuania, Poland, and St. Petersburg region (Russia).

Aiming to get a more systematic and generalized picture, Quadruple Helix Model of innovation (Carayannis \& Campbell, 2009) was used. This model is first applied to identify potential experts from the key stakeholders dealing with the pioneering transformative tourism projects. The Quadruple Helix Model recognizes four major groups of actors in the innovation system:

1) Business;

2) Government;

3) Academia (universities and research institutes);

4) Civil society organizations (social movement and NGOs).

Each stakeholder group, following the Quadruple Helix Model methodology, must be represented by experts in the field. Expert selection in every stakeholder group (stakeholder mapping) was grounded on the Stakeholder salience model (Mitchell et al, 1997, p. 874), which is based on the 3 main criteria when measuring their power, urgency, and legitimacy:

- Legitimacy: Why is he/she a stakeholder/suitable expert in the field? (e.g., policy beneficiary, implementer, decision-maker, financer, businessman, scientist, etc.);

- Urgency (interest): What interest does he/she have on tourism and/or transformative ecotourism situation?

- Power: What power does he/she hold for changing tourism and/or transformative ecotourism situation in the country/region?

The stakeholder mapping process resulted in a set of identified stakeholders, who hold high urgency, legitimacy, and power parameters regarding tourism development in the Baltic Sea 
Region. Therefore, results of stakeholder mapping in the selected Baltic Sea Region countries give the following composition of appropriate tourism experts (see Table 1), who were further surveyed using a structured survey questionnaire.

Tab 1. Distribution of interviewed experts by country and sector. Source: Calculated by authors according to expert survey results

\begin{tabular}{|c|c|c|c|c|c|c|c|c|c|c|}
\hline \multirow{3}{*}{$\begin{array}{l}\text { Sector } \\
\text { Representation } \\
\text { percentage per } \\
\text { sector }(\%) \text { and } \\
\text { number of surveyed } \\
\text { experts }(n)\end{array}$} & \multicolumn{10}{|c|}{ Responses } \\
\hline & \multicolumn{2}{|c|}{ Latvia } & \multicolumn{2}{|c|}{ Lithuania } & \multicolumn{2}{|c|}{ Poland } & \multicolumn{2}{|c|}{$\begin{array}{l}\text { St. Petersburg } \\
\text { region } \\
\text { (Russia) }\end{array}$} & \multicolumn{2}{|c|}{ Total } \\
\hline & $\%$ & $\mathrm{n}$ & $\%$ & $\mathrm{n}$ & $\%$ & $\mathrm{n}$ & $\%$ & $\mathrm{n}$ & $\%$ & $\mathrm{~N}$ \\
\hline Business & 17.65 & 3 & 17.65 & 3 & 18.75 & 3 & 14.29 & 2 & 17.19 & 11 \\
\hline Government & 23.53 & 4 & 17.65 & 3 & 31.25 & 5 & 7.14 & 1 & 20.31 & 13 \\
\hline Academia & 35.29 & 6 & 29.41 & 5 & 31.25 & 5 & 42.86 & 6 & 34.38 & 22 \\
\hline $\begin{array}{l}\text { Society(social } \\
\text { movements and } \\
\text { NGOs) }\end{array}$ & 23.53 & 4 & 35.29 & 6 & 18.75 & 3 & 35.71 & 5 & 28.13 & 18 \\
\hline Total: & 26.56 & 17 & 26.56 & 17 & 25.00 & 16 & 21.88 & 14 & 100 & 64 \\
\hline
\end{tabular}

The elaborated composition of tourism experts is based on their expertise experience and ability to represent the region, based on mentioned urgency, legitimacy, and power parameters. In those regions, where experts held moderate value (not the definitely high) regarding any of the three mentioned parameters, more experts had been added to better represent the state of the country/region regarding the survey issue. For example, government representatives' mounts differ in the two regions: St. Petersburg region (Russia) $n=1$, from Poland $n=5$ (see Table 1), but both regions are similarly represented by expertise considering all three parameters, i.e., urgency, legitimacy, and power.

A structured survey questionnaire consisted of questions concerning the importance of the two sets of barriers for transformative ecotourism development: first, policy and regulation barriers to entry into the transformative ecotourism sector; and second, economic barriers related to regional economic development. Experts were asked to value the proposed lists of tourism barriers, using the 5-point Likert scale, ranging from " 1 - Strongly agree" to "5 - Strongly disagree". Next to every list of barriers, a free option was given to add other relevant barriers corresponding to the valued area. At the end of the survey, experts had an opportunity to list any other relevant barriers for ecotourism development since they had not been provided in the survey questionnaire.

The expert survey in four Baltic Sea Region countries/regions was done in October - December 2020. In total, all 64 filled-in survey questionnaires were found appropriate for further analysis. Further, descriptive statistical analysis was used to analyze the expert survey results.

\section{Research results}

Analysis of expert survey results firstly aimed to identify the relevance of every proposed barrier for overall transformative ecotourism development, and secondly, to identify the distinction between the expert measures of every listed barrier in the four researched countries. The following initial presumptions had been made for analysis: firstly, the barrier will be defined as irrelevant and eliminated from further analysis in case the weighted average value is greater than 4 (5 is maximum for strong disagreement regarding the existing barrier); and, secondly, the lower the weighted average value is (i.e., closer to the center of the network diagram), the more important respective barrier is. 
Aggregated research results elucidate (see Figure 1a and Figure 1b), that none of the proposed barriers is found irrelevant for transformative ecotourism development since none of the barriers received greater value than 4 . Such a situation is common when a new phenomenon is emerging, and normally much is to be done for creating a favorable environment for its further development. Thus, the full proposed lists of policy and regulation, as well as economic barriers, were used for further analysis.

Figure 1a. Weighted averages of policy and regulation barriers
Figure 1b. Weighted averages of economic barriers
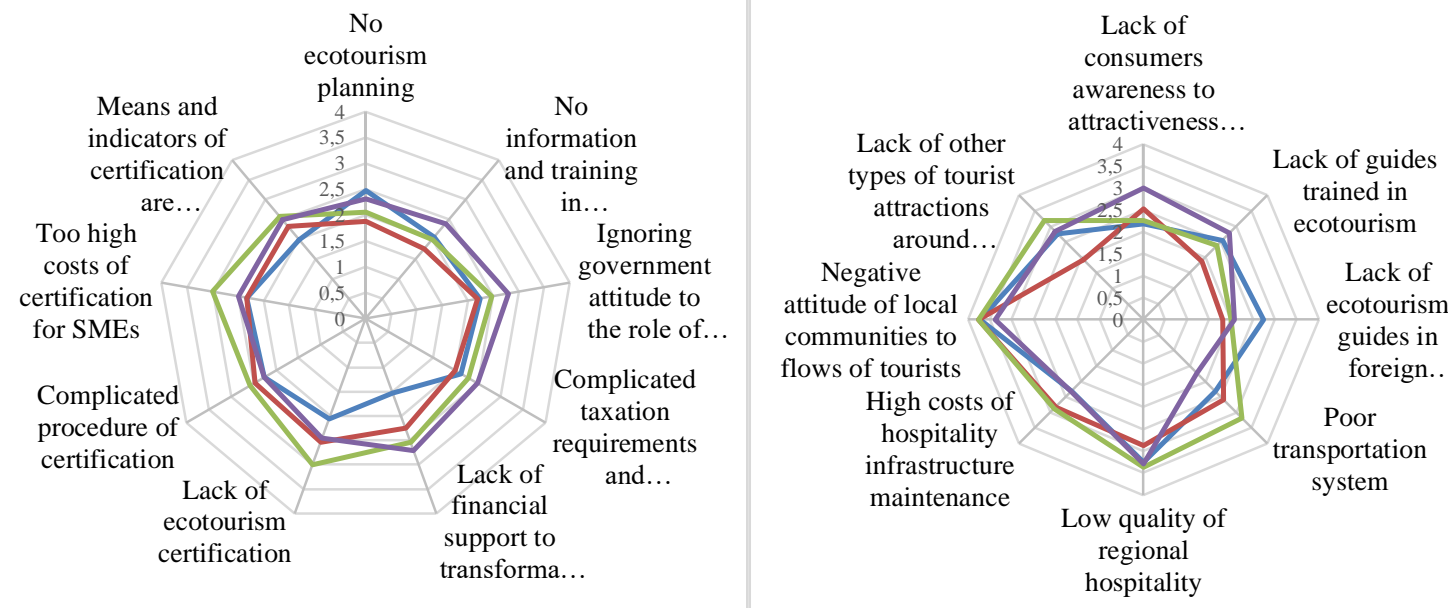

$\longrightarrow$ Latvia $\longrightarrow$ Lithuania $\longrightarrow$ Poland $\longrightarrow$ Russia
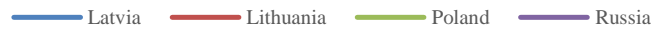

Source: Arranged by authors according to expert survey results

Aggregated survey data further reveals that the overall state of transformative ecotourism development is complicated in all researched countries since all the proposed barriers were defined by experts as relevant (ranging from " 1 " as very important to "3" as medium importance value), only to a slightly different level: regarding the policy and regulation issues, the weighted average of answers ranges from 1.75 to 3 , and economic barriers in the weighted average of answers vary between 1.73 to 3.75. It should be stated here, that none of the proposed barriers are critical for further development of transformative ecotourism. They just give directions for improvement in the field.

Hence, at the same time, research results elucidate that barriers are common for all countries. According to the weighted average of experts' answers, there does not exist a significant difference among particular barriers in researched countries, since the distance of weighted average values is quite insignificant (see Figure 1a and Figure 1b).

Only Polish experts distinguished the lack of ecotourism certification and too high costs of certification for SMEs as the least important policy and regulation barriers, but it concerns the development of all forms of ecotourism, not only transformative ecotourism. Regarding the economic barriers, all countries' experts agree, that the least concerns should be given to the negative attitude of local communities to flows of tourists and low quality of regional hospitality. Hence, the poor transportation system seems to be the least important barrier only for Polish experts.

Overall, weighted averages analysis is useful only in terms of making a general picture of the state of the art in different researched regions. It does not give a clear answer, what are the most important barriers in researched countries in the two areas: i) policy and regulation and ii) regional economic development. Therefore, further analysis was fulfilled by rating the transformative 
ecotourism barriers in every country, using the aggregated experts' answers by category "Strongly agree".

\subsection{Policy and regulation barriers for the development of transformative ecotourism}

Rating results of policy and regulation barriers, based on the "Strongly agree" position as driving evaluation criteria, in all four researched countries/regions, propose significant findings with particular similarities and differences (see Figure 2).

An overall picture of policy and regulation barriers in researched countries(regions) suggests, that, from a first sight, there exist particular tendencies that might help define the most relevant further policy and regulation improvement directions in the promotion of the transformative ecotourism. Further in-depth research of expert survey results was focused on the top-5 most important barriers in every researched country/region, that received the highest degree of expert that have selected an option „Strongly agree“. Research results were aggregated using a barriers“ position rating number among the top- 5 barriers in every country.

Aggregated research results revealed that seven policy and regulation barriers are found most important for transformative ecotourism development in the researched regions. These barriers in most cases only change the rating position in a particular country, nevertheless, it remains identified among the top- 5 barriers in the country. The greatest agreement on the main obstacle (the $1^{\text {st }}$ position in Latvia and Poland) is devoted to the lack of information and training in transformative ecotourism business, which signalizes the emerging phenomena and the need to deepen overall knowledge and understanding of the phenomenon. The $2^{\text {nd }}$ position address the issues of ecotourism planning, as stated by experts from the three researched countries/regions (Latvia, Poland, and St. Petersburg (Russia)). The $3^{\text {rd }}$ rating position was commonly agreed by Lithuanian and Polish experts stating the complicated taxation requirements and procedures for transformative ecotourism development. This also signalized the necessary improvements in policy and regulation, aiming to create a more favorable environment for transformative ecotourism development. Hence the $4^{\text {th }}$ rating position, shared by Polish and Russian experts, also concerns the governments' attitudes namely, ignoration from the government side towards the role of this innovative tourism form and its prospective potential. The $5^{\text {th }}$ rating position varied among the listed barriers in all researched regions. Thus, the aggregated research results regarding the policy and regulation barriers for transformative ecotourism development highly address the increasing role of government in creating a more favorable environment for this innovative tourism form. 


\section{Figure 2. Policy and regulation barriers for transformative ecotourism} development

LATVIA: No information and training in transformative.

$$
\text { No ecotourism planning }
$$

Means and indicators of certification are inadequate for

$$
\text { Lack of ecotourism certification }
$$

Ignoring government attitude to the role of this innovative.

Too high costs of certification for SMEs

Complicated procedure of certification

Lack of financial support to transformative ecotourism projects

Complicated taxation requirements and procedures

LITHUANIA: Lack of financial support to transformative.

Lack of ecotourism certification

Complicated taxation requirements and procedures

Means and indicators of certification are inadequate for.

No information and training in transformative ecotourism business

Ignoring government attitude to the role of this innovative.

Complicated procedure of certification

Too high costs of certification for SMEs

No ecotourism planning

POLAND: No information and training in transformative.

No ecotourism planning

Complicated taxation requirements and procedures

Ignoring government attitude to the role of this innovative.

Lack of financial support to transformative ecotourism projects

Means and indicators of certification are inadequate for

Complicated procedure of certification

Lack of ecotourism certification

Too high costs of certification for SMEs

ST. PETERSBURG REGION (RUSSIA): Lack of ecotourism.

No ecotourism planning

Lack of financial support to transformative ecotourism projects

Ignoring government attitude to the role of this innovative.

Complicated taxation requirements and procedures

No information and training in transformative ecotourism business

Means and indicators of certification are inadequate for.

Complicated procedure of certification

Too high costs of certification for SMEs
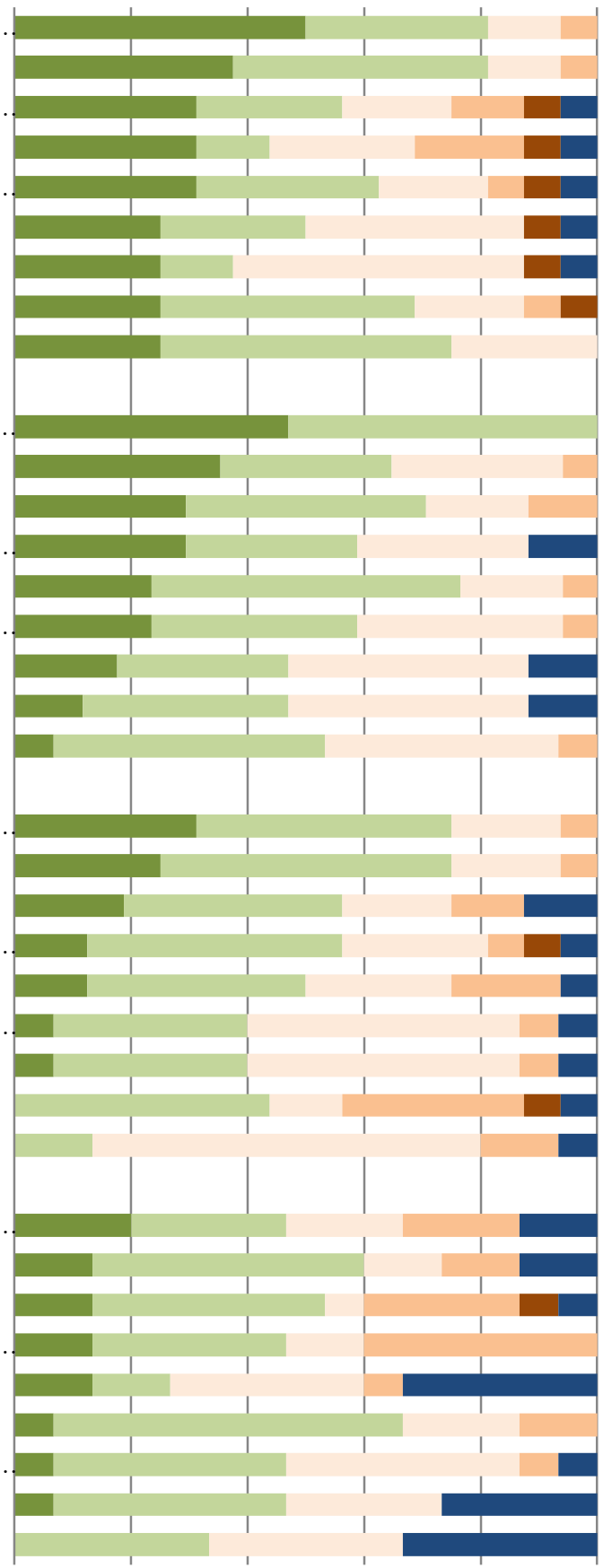

$\begin{array}{llllll}0 \% & 20 \% & 40 \% & 60 \% & 80 \% & 100 \%\end{array}$

$\square$ Strongly agree $\square$ Agree $\quad$ Neither agree nor disagree $\square$ Disagree $\quad$ Strongly disagree $\square$ N/A

Source: Calculated by authors according to expert survey results 


\section{Economic barriers for the development of transformative ecotourism}

Further analysis was devoted to transformative ecotourism development barriers, focusing on the economic situation in the region. Overall, summarized findings from the expert survey propose the existence of particular similarities among the researched countries/regions when taking into account the "Strongly agree" rating criteria of distinguished economic barriers (see Figure 3).

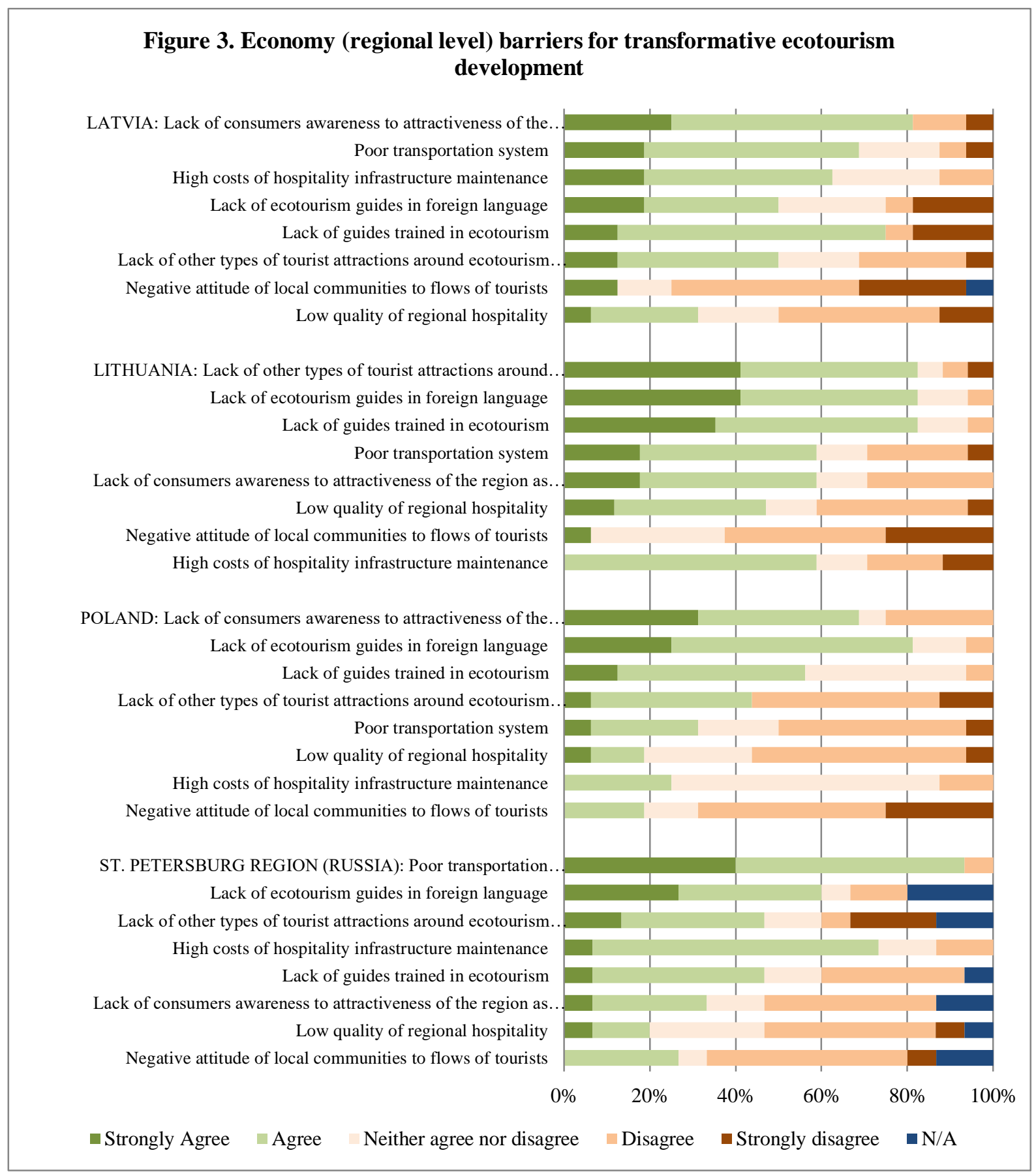

Source: Calculated by authors according to expert survey results

The overall picture of rating results demonstrates, that, in contrast to the examined situation regarding the policy and regulation, particular proposed economic barriers more often received from experts' "Strongly disagree", which demonstrates a greater distribution of experts' attitudes towards the proposed economic barriers. 
Since the overall picture of economic barriers for transformative ecotourism development does not give a concrete answer, which of the barriers are the most important for all researched regions, further analysis was done again using the top- 5 barrier rating method.

Aggregated expert survey results concerning the top-5 economic barriers for transformative ecotourism development reveals, that there exist six major barriers in the field, and it is less compared to policy and regulation barriers. At the same time, this situation demonstrates, that distinguished economic barriers received greater agreement among researched regions. The $1^{\text {st }}$ position in Latvia and Poland had been occupied by the barrier, related to consumers' awareness of the attractiveness of the region as the tourism destination. This barrier had been given the $5^{\text {th }}$ position by Lithuanian experts. Lack of ecotourism guides in foreign language truly occupied the $2^{\text {nd }}$ rating place among the other barriers from the joint view of Lithuanian, Polish, and Russian experts. Very close - the $3^{\text {rd }}$ position had been given to the lack of guides trained in ecotourism, which was found very important by Lithuanian and Polish experts; hence Latvian and Russian experts put this barrier into the $5^{\text {th }}$ rating place. The $4^{\text {th }}$ rating position varied among the listed economic barriers by country.

Summarized results of economic barriers for transformative ecotourism development demonstrate, that the key focus for creating a more favorable environment for this innovative form of tourism, should be twofold. First, appropriate infrastructure is necessary, taking into account hospitality and transportation system, moreover, just simply - ecotourism guides in a foreign language (!). Second, special attention should be given to educating the demanded human resources, that would be able to understand the essence of transformative ecotourism, its advantages and to translate this to a broader audience of coming tourists, who might become the prosperous advocators of this prospective innovation in their regions on residence or their lifestyles.

\section{Other barriers for transformative ecotourism development}

Surveyed experts had been also provided an opportunity to add any relevant barriers for transformative ecotourism development as an open answer concerning policy and regulation and economic issues, as well as any other relevant obstacles they see in the field. Summarized expert's views are explored in Table 2.

Summarized survey results elucidate both the differences and similarities in relevant obstacles for transformative ecotourism development in the four researched countries, as well as among sectors. Academia and science representatives from Latvia outlined the need for updating ecotourism education from the policy and administrative point of view. Russian academic representatives stressed the lack of administrative support at the political and regulation level for transformative ecotourism development. Among the economic obstacles, academia and science representatives from Latvia stated, that particular issues exist in updating ecotourism products in the context of season extension. Polish scientists outlined low ecotourism attraction as compared to the neighboring areas as an economic obstacle. Lithuanian business representatives stated, that the lack of tourism flow creates an economic loop for further development of the sector: low tourism flow leads to low income, further - no investment to improve and/or create new infrastructure; and then, again: the fewer tourists are coming, the less income business generates. Therefore, the need for another income source of income is necessary and thus businessmen, operating in the field, should necessarily manage the diversification of their business activity.

Among the other existing barriers for ecotourism development, both Latvian and Lithuanian academia and science representatives, as well as Lithuanian government representatives, stressed the lack of understanding of ecotourism in general and in its urgency in a broader sense. Russian scientists stressed the lack of administrative and information support in a form of special centers of cooperation, as well as lack of inclusive environment as the barriers for transformative ecotourism development. Scientists from Lithuania also observed the lack of marketing skills of local entrepreneurs as an obstacle for further developments in the field. Business representatives from Lithuania highlighted the problem of the existing contradiction between traveling and ecology in general. Polish government representatives issued several barriers for transformative ecotourism development, firstly stating the global pandemic of Covid-19. They also observe 
particular important difficulties regarding the undeveloped tourism and accommodation facilities for transformative ecotourism, as well as a lack of independent strategy for such activities from the government side. Polish society representatives address the existing situation of undeveloped ecotourism in Poland to the 'no change necessary' attitude among the companies, local and regional administration. Whereas Lithuanian society representatives see the key challenge more technically, relating it to insufficient visibility and dissemination in terms of information on transformative ecotourism places on the Internet and on the ground at local places.

Tab 2. Other barriers for transformative ecotourism development in the four Baltic Sea Region countries. Source: Arranged by authors according to expert survey results

\begin{tabular}{|c|c|}
\hline \multicolumn{2}{|l|}{ Policy and regulation barriers } \\
\hline Latvia & - Updating of ecotourism education. \\
\hline St. Petersburg region (Russia) & - Lack of administrative support. \\
\hline \multicolumn{2}{|l|}{ Economic barriers } \\
\hline Latvia & - Updating ecotourism products in the context of season extension. \\
\hline Lithuania & $\begin{array}{l}\text { - The loop of lack of tourism flow - lacking income - no investment } \\
\text { to infrastructure - less tourists coming - less income; } \\
\text { - the need for another income source. }\end{array}$ \\
\hline Poland & - Low ecotourism attraction as compared to the neighboring areas \\
\hline \multicolumn{2}{|l|}{ Other barriers } \\
\hline Latvia & - Understanding of ecotourism in a broader sense. \\
\hline Lithuania & $\begin{array}{ll} & \text { A contradiction between traveling and ecology in general; } \\
\text { - } & \text { insufficient visibility and dissemination of information on } \\
& \text { transformative ecotourism places on the Internet and the ground } \\
& \text { at local places; } \\
\text { - lack of marketing skills of local entrepreneurs; } \\
\text { - } \quad \text { understanding of ecotourism in general. }\end{array}$ \\
\hline Poland & $\begin{array}{l}\text { - } \\
\text { - } \\
\text { no development of tourism and accommodation facilities; } \\
\text { - } \quad \text { 'no change necessary' attitude among the companies, local and } \\
\text { regional administration; } \\
\text { - } \quad \text { lack of independent strategy for such activities. }\end{array}$ \\
\hline St. Petersburg region (Russia) & $\begin{array}{l}\text { - Lack of administrative/information support like special centers of } \\
\text { cooperation; } \\
\text { - lack of inclusive environment. }\end{array}$ \\
\hline
\end{tabular}

\section{Conclusions}

The research findings allow end-users - entrepreneurs and policymakers - to focus on key areas where change needs to take place and innovate effectively. Transformative tourism development policies have a long-term perspective as regions benefit by enabling an efficient allocation of intangible resources, generating employment opportunities, opening up new markets, contributing to the sustainability of local small businesses, etc. At the same time, the development of transformative ecotourism leads to inclusive regional development which is focusing on how to overcome the exclusion of local people from access to the tourism business.

Empirical findings signalize that transformative ecotourism is a new phenomenon, and many policy and regulation, as well as economic obstacles, should be overcome. The starting flag is waving with demanded improvements from the government side concerning soft policy and regulation issues in the field. It also calls for necessary infrastructure and maintenance and other related improvements. However, the very first challenge for further developments in the field is a newly educated generation, since next to the commonly rated barriers for transformative ecotourism development in researched countries, among other meaningful obstacles, the general understanding of the phenomena in a broader sense, as well as unreadiness to receive the benefits from it is evident. The unwillingness to change both by companies, local and regional 
administrations leads to the lack of decisions related to strategic issues, further administrative and political support, as well as a passive business role in the field.

Overall, research results demonstrate, that transformative ecotourism is an emerging phenomenon, and its potential in solving the future issues of the tourism sector in volatile transformations needs to be accelerated firstly by creating favorable conditions to act in the field, from the government side in terms of policies and regulations. And further developments in the field will highly depend on broadening understanding of the ecotourism vision, its educational effects and total benefit to society, which currently remain unrecognized and unresearched, but, in turn, might accelerate prospective innovations in tourism business models.

\section{Acknowledgement}

The research was conducted as a part of INTERREG Baltic Sea Region Programme 2014-2020 SEED project "Unlocking transformative ecotourism potential for sustainable regional development - RESTinBSR" (No. \#S060). The partners of the project represented Lithuania, Latvia, Poland and the region of St Petersburg (Russia).

Academic references

[1] Budge, I. (2000). Expert judgements of party policy positions: Uses and limitations in political research. European Journal of Political Research, 37(1), 103-113. DOI: 10.1111/14756765.00506.

[2] Butcher, J. (2011). Tourism and poverty reduction: Pathways to prosperity. Journal of Policy Research in Tourism, Leisure and Events, 3(1), 99-101. DOI: $10.1080 / 19407963.2011 .539385$.

[3] Carayannis, E. G. \& Campbell, D. F. (2009). 'Mode 3'and'Quadruple Helix': toward a 21st century fractal innovation ecosystem. International Journal of Technology Management, 46(3-4), 201-234.

[4] Carrier, J. G. \& Macleod, D. V. L. (2005). Bursting the Bubble: The Socio-Cultural Context of Ecotourism. Journal of the Royal Anthropological Institute, 11, 315-334. DOI: 10.1111/j.1467-9655.2005.00238.x.

[5] Carvache-Franco, M., Segarra-Oña, M. \& Carrascosa-López, C. (2019). Segmentation by Motivation in Ecotourism: Application to Protected Areas in Guayas, Ecuador. Sustainability, 11(1), 240. DOI: 10.3390/su11010240.

[6] Collins, A. (1999). Tourism development and natural capital. Annals of Tourism Research, 26(1), 98-109. DOI: 10.1016/S0160-7383(98)00059-0.

[7] Coria, J. \& Calfucura, E. (2012). Ecotourism and the development of indigenous communities: The good, the bad, and the ugly. Ecological Economics, 73, 47-55. DOI: 10.1016/j.ecolecon.2011.10.024.

[8] Das, S. (2011). Ecotourism, sustainable development and the Indian state. Economics and Political Weekly, 46(37), 60-67.

[9] Das, M. \& Chatterjee, B. (2015). Ecotourism: A panacea or a predicament? Tourism Management Perspectives, 14, 3-16. DOI: 10.1016/j.tmp.2015.01.002.

[10] Diamantis, D. (1999). The concept of ecotourism: Evolution and trends. Current Issues in Tourism, 2(2-3), 93-122. DOI: 10.1080/13683509908667847.

[11] Drumm, A. (2008). The Threshold of Sustainability for Protected Areas. Bioscience, 58, 782783. DOI: 10.1016/j.tourman.2009.08.012.

[12] Duffy, R. (2002). A Trip Too Far: Ecotourism Politics and Exploitation. London: Earthscan Publications. DOI: 10.4324/9781849770347. 
[13] Erdoğan, N. (2017). Critical views of mainstream approaches on ecotourism. Journal of Tourism and Gastronomy Studies, 5(1), 20-31. DOI: 10.21325/jotags.2017.56.

[14] Fennell, D. A. (2020). Ecotourism. London: Routledge.

[15] Filion, F. L., Foley, J. P. \& Jacquemont, A. J. (1994). The economics of global ecotourism. In Munasinghe, M. \& McNeely, J., eds., Protected Area Economics \& Policy, Linking Conservation \& Sustainable Development (pp. 235-252). Washington, DC: World Bank.

[16] Gray, N. J. \& Campbell, L. M. (2007). A Decommodified Experience? Exploring Aesthetic, Economic and Ethical Values for Volunteer Ecotourism in Costa Rica. Journal of Sustainable Tourism, 15(5), 463-482. DOI: 10.2167/jost725.0.

[17] Hjalager, A. M. (2010). A review of innovation research in tourism. Tourism Management, 31(1), 1-12. DOI: 10.1016/j.tourman.2009.08.012.

[18] Holden, A. (2003). In Need of New Environmental Ethics for Tourism? Annals of Tourism Research, 30, 94-108. DOI: 10.1016/S0160-7383(02)00030-0.

[19] Khanra, S., Dhir, A., Kaur, P. \& Mäntymäki, M. (2021). Bibliometric analysis and literature review of ecotourism: Toward sustainable development. Tourism Management Perspectives, 37, 100777. DOI: 10.1016/j.tmp.2020.100777.

[20] Kim, M., Xie, Y. \& Cirella, G. T. (2019). Sustainable transformative economy: communitybased ecotourism. Sustainability, 11(18), 4977. DOI: 0.3390/su11184977.

[21] Lee, J. H. (2019). Conflict mapping toward ecotourism facility foundation using spatial $Q$ methodology. Tourism Management, 72, 69-77. DOI: 10.1016/j.tourman.2018.11.012.

[22] Macbeth, J. (2005). Towards an ethics platform for tourism. Annals of Tourism Research, 32(4), 962-984. DOI: 10.1016/j.annals.2004.11.005.

[23] McCauley, D. J. (2006). Selling out on nature. Nature, 443(7107), 27-28. DOI: $10.1038 / 443027 a$.

[24] McCool, S. F. \& Lime, D. W. (2001). Tourism carrying capacity: tempting fantasy or useful reality? Journal of Sustainable Tourism, 9(5), 372-388. DOI: 10.1080/09669580108667409.

[25] McShane, T. O., Hirsch, P. D., Trung, T. C., Songorwa, A. N., Kinzig, A., Monteferri, B., Mutekanga, D., Van Thang, H., Dammert, J. L., Pulgar-Vidal, M., Welch-Devine, M., Brosius, J. P., Coppolillo, P. \& O'Connor, S. (2011). Hard choices: Making trade-offs between biodiversity conservation and human well-being, Biological Conservation, 144(3), 966-972. DOI: 10.1016/j.biocon.2010.04.038.

[26] Mitchell, J. \& Ashley, C. (2010). Tourism and Poverty Reduction, London: Earthscan.

[27] Monti, F., Duriez, O., Dominici, J. M., Sforzi, A., Robert, A., Fusani, L. \& Grémillet, D. (2018). The price of success: integrative long-term study reveals ecotourism impacts on a flagship species at a UNESCO site. Animal Conservation, 21(6), 448-458. DOI: 10.1111/acv.12407.

[28] Page, S. J. \& Dowling, R. K. (2001). Ecotourism. London: Pearson Education Limited.

[29] Palojärvi, A., Pyysiäinen, J. \& Saloranta, M., eds. (2013). Experiences with ecological technologies and practices: inspiring stories from ecovillages. Vilnius: LAEI.

[30] Panin, B. \& Mbrica, A. (2014). Potentials of Ecotourism as a Rural Development Tool on the Base of Motivation Factors in Serbia. Sofia: Institute of Agricultural Economics.

[31] Peake, S., Innes, P. \& Dyer, P. (2009). Ecotourism and conservation: Factors influencing effective conservation messages. Journal of Sustainable Tourism, 17(1), 107-127. DOI: 10.1080/09669580802276000.

[32] Perdomo, Y., ed. (2016). Global Report on the Transformative Power of Tourism: A Paradigm Shift Towards a More Responsible Traveller. Madrid: World Tourism Organization.

[33] Reisinger, Y., ed. (2013). Transformational tourism: Tourist perspectives. Wallingford: Cabi. DOI: 10.1079/9781780642093.0000. 
[34] Reisinger, Y., ed. (2015). Transformational tourism: Host perspectives. Wallingford: Cabi. DOI: 10.1079/9781780643922.0000.

[35] Ruhanen, L. (2019). The prominence of eco in ecotourism experiences: An analysis of postpurchase online reviews. Journal of Hospitality and Tourism Management, 39, 110-116. DOI: 10.1016/j.jhtm.2019.03.006.

[36] Schedler, A. (2012). Judgment and Measurement in Political Science. Perspectives on Politics, 10(1), 21-36.

[37] Sorensen, F. (2011). Inducing user-driven innovation in tourism: an experimental approach. In Sundbo, J. \& Toivonen, M., eds., User-based Innovation in Services (pp. 323-346). Cheltenham: Edward Elgar. DOI: 10.4337/9780857931962.00025.

[38] Tully, J. (2001). An Ecological Ethics for the Present: Three Approaches to the Central Question. In Gleeson, B. \& Low, N., eds., Governing for the Environment: Global Problems, Ethics and Democracy (pp. 147-164). Basingstoke: Palgrave. DOI: $10.1057 / 9780333977620$.

[39] Vidickiene, D. (2013). Living in harmony: inspiring stories from ecovillage. Vilnius: LAEI.

[40] Vidickiene, D., Gedminaite-Raudone, Z. \& Simonaityte, V. (2019). Servitization of farming: manifestations of the business model «Product plus services» in Lithuania. Vilnius: LAEI.

[41] Vidickiene, D., Vilke, R. \& Gedminaite-Raudone, Ž. (2020). Transformative Tourism as an Innovative Tool for Rural Development. European Countryside, 12(3), 277-291. DOI: 10.2478/euco-2020-0016.

[42] Wardle, C., Buckley, R., Shakeela, A. \& Castley, J. G. (2018). Ecotourism's contributions to conservation: Analysing patterns in published studies. Journal of Ecotourism, 3(14), 1-31. DOI: $10.1080 / 14724049.2018 .1424173$.

[43] Wondirad, A. (2019). Does ecotourism contribute to sustainable destination development, or is it just a marketing hoax? Analyzing twenty-five years contested journey of ecotourism through a meta-analysis of tourism journal publications. Asia Pacific Journal of Tourism Research 24(11), 1047-1065. DOI: 10.1080/10941665.2019.1665557.

[44] Wiesehomeier, N., (2018). Expert surveys. In Hawkins, K. A., Carlin, R., Littvay, L. \& Kaltwasser, C. R., eds., The ideational approach to populism: Concept, theory, and analysis, (pp. 90-101). London: Routledge.

Other sources

[45] Call for Proposals: Innovative approaches to urban and regional development through cultural tourism. Retrieved May 27, 2021, from https://clustercollaboration.eu/news/callproposals-innovative-approaches-urban-and-regional-development-through.

[46] Ceballos-Lascurain, H. (1987). The future of 'ecotourism', Mexico Journal, January, 13-14.

[47] Norris, P. \& Skaaning, S. E. (2016). The construction and use of expert surveys in the social sciences. Closed Panel of the IPSA World Congress, Istanbul 23-28 July 2016. Retrieved January 23, 2021, from https://www.vdem.net/files/2/IPSA\%20expert\%20survey\%20panel\%20Call\%20for\%20Papers.pdf.

[48] Report on Sustainable Tourism in the Baltic Sea Region (2020). Baltic Sea Parliamentary Conference. Retrieved May 27, 2021, from http://www.bspc.net/wpcontent/uploads/2020/10/BSPC_WorkingGroupSustainableTourism_2020.pdf.

[49] Starmer-Smith, C. (2004). Eco-friendly tourism on the rise. Daily Telegraph Travel, 6(4).

[50] TIES (2015). The International Ecotourism Society. https://ecotourism.org/what-isecotourism/. 